\title{
Adoption of Banana Disease Management Practices and Constraints of Banana Growers in Kalaburagi District of Karnataka, India
}

\author{
Sureshbabu*, B. Zaheer Ahamed, Basayya and S.K. Jayalakshmi \\ Department of Plant Pathology, College of Agriculture, Kalaburagi, University of Agricultural \\ Sciences, Raichur-584104, Karnataka, India \\ *Corresponding author
}

\section{A B S T R A C T}

\begin{tabular}{|l|}
\hline Ke y w or d s \\
Banana, Farming \\
practices, Adoption, \\
constraints.
\end{tabular}

A study was conducted in Kalaburagi district of Karnataka during 2015-16 to check the disease management practices in tissue culture and sucker sown banana orchards. The district covers only 19\% irrigation facility but good rain set up, Horticulture department encouragement and Agriculture university scientists' guidance this study reveals that most of the farmers (41.5\%) belonged to medium level range farmers are quick in adoption of tissue culture banana farming practices. In shallow and low clay content soils the banana growers adopted desuckering practices where in correct size pit opening, spacing, season and in time planting, FYM, NPK and micronutrient, drip irrigation, powder form and liquid form of trichoderma and pseudomonas application and timely plant protection measures carried out varied from farmer to farmer and place to place.

\section{Introduction}

India is the largest producer of banana in the world having an area of about 657 thousand ha with production of 23215 thousand MT. In Karnataka area under Banana cultivation is 61.4 thousand ha with annual production of 1614 thousand MT. Banana contributes to 35 percent of the total fruit production. In Kalaburagi area under banana is 1750 ha with production of 47115tons.Banana is a nutritious gold mine. It is high in vitamin B6 which helps to fight against infections and is essential for the synthesis of heme, the iron containing part of haemoglobin. It is also rich in potassium and is a prominent source of fiber. The present study was undertaken to document the adoption in disease management practices and constraints faced by the banana in Kalaburagi district of Karnataka.

\section{Materials and Methods}

The present study was conducted during 2015-16 in Kalaburagi district of north Karnataka. The district was known for high temperature and fruit demanding is more during summer and thus selected because it had more area under banana cultivation due to NHM scheme in Horticulture department. From each of the four selected Taluks of Kalaburagi district five villages and five farmers from each village were selected for the study purpose which covering 100 
respondents in total. The recommended pest and disease management practices and banana cultivation practices were selected to form an adoption test. The response elicited from the respondents was qualified as full, partial and non-adoption of the recommended practices. Similarly the respondents were asked to indicate the constraints faced by them in adoption of the recommended were tabulated and analysed using frequency and percentage. The knowledge level and farmer education also documented during the study.

\section{Results and Discussion}

The results were shown in table 1 which indicates that most of the farmers $(45.83 \%)$ belonged to medium level of adoption followed by 30.3 and 18.6 per cent belonging to low and high level of adoption category respectively. The reasons for majority in medium level of adoption category might be their medium level of knowledge, mass media exposure utility, extension contact and tendency of economic motivation, risk bearing ability and innovativeness.

Table.1 Distribution of respondents according to their overall adoption of banana cultivation

$$
\text { practices }(n=100)
$$

\begin{tabular}{lll}
\hline Category & Frequency & Percentage \\
\hline Low $(<6)$ & 23 & 18.6 \\
Medium $(6 .--7.50)$ & 52 & 41.74 \\
High $(>7.50)$ & 38 & 30.35 \\
\hline
\end{tabular}

Mean $=6.83, \mathrm{SD}=1.23$

Table.2 Distribution of respondents according to adoption of individual banana cultivation practices $(n=100)$

\begin{tabular}{|c|c|c|c|c|c|c|}
\hline \multirow[t]{2}{*}{ Practice } & \multicolumn{2}{|c|}{ Fully adopted } & \multicolumn{2}{|c|}{ Partially adopted } & \multicolumn{2}{|c|}{ Not adopted } \\
\hline & Frequency & $\%$ & Frequency & $\%$ & Frequency & $\%$ \\
\hline Tissue B & 82 & 94.17 & 7 & 5.83 & 0 & 0.00 \\
\hline Spacing & 80 & 91.67 & 9 & 7.50 & 1 & 0.83 \\
\hline Pit size & 87 & 74.17 & 19 & 15.83 & 12 & 10.00 \\
\hline \# suckers & 47 & 78.33 & 15 & 12.50 & 11 & 9.17 \\
\hline \multicolumn{2}{|c|}{ Sucker treatment 05} & 5.83 & 12 & 10.00 & 68 & 54.17 \\
\hline Sucker type & 33 & 82.50 & 14 & 11.67 & 7 & 5.83 \\
\hline Weed control & 18 & 19.17 & 12 & 12.0 & 56 & 50.83 \\
\hline FYM & 86 & 75.00 & 30 & 25.00 & 0 & 0.00 \\
\hline Desuckering & 90 & 100.00 & 0 & 0.00 & 0 & 0.00 \\
\hline Pest control & 50 & 50.00 & 30 & 25.00 & 30 & 25.00 \\
\hline Disease control & 48 & 50.00 & 4 & 3.33 & 56 & 46.67 \\
\hline
\end{tabular}


Table.3 Distribution of respondents according to their constraints of banana cultivation $(n=100)$

\begin{tabular}{lcc}
\hline Problem & Frequency & $\%$ \\
Financial problem & 87 & 85.00 \\
Electricity problem & 78 & 82.83 \\
Cost of tissue culture plants & 56 & 84.17 \\
Lack of knowledge about ICM & 55 & 80.83 \\
Non-available of planting material & 44 & 40.00 \\
Non-availability of chemical fertilizers & 57 & 45.83 \\
Labour problem & 92 & 94.17 \\
Storage facility problem & 95 & 90.00 \\
Exploitation by middleman & 80 & 80.00 \\
Lack of knowledge about value added products & 98 & 98.17 \\
\hline
\end{tabular}

The data presented in table 2 reveal that the adoption of detailed recommended cultivation practices in order of priority were 50 per cent of banana growers adopted desuckering practices followed by variety (82\%), spacing $(80 \%)$, number of suckers $(47 \%)$, pit size $(87 \%)$, pest control and disease control $(50.00 \%)$. The data also reveal that the respondents not shown much interest to adopt chemical weed control $(18 \%)$ and sucker treatment $(5 \%)$. IT might be due to lack of regular training in sucker treatment and poor knowledge about weed control. The findings of the study are in agreement with the results of obtained by Hanumaniakar (1995), Wase (2001) and Sudhakar (2002). Among the different constraints (Table 3) labour (92\%), electricity problem (72\%), Storage facility (95\%). ICM knowledge 55\%) were the main problems of the farmers whereas non-availability of planting material $(30.00 \%)$ was noticed in the studies of Sreenivasreddy (1995), Sharma (1997) and Ravikumar (2010).

\section{References}

Hanumanaikar RH 1995. A study on knowledge adoption of marketing behaviour of sunflower growers in Dharwad district. M.Sc.(Agric) thesis.

Ravikumar M 2010. A study on knowledge and adoption of post -harvest management practices among the mango growers of northern Karnataka. MSc(Agric) thesis, University of Agricultural Sciences, Dharwad, Karnataka, India.

Sharma DD 1997. Constraints in adoption of recommended mango cultivation practices by growers. Maharashtra J. Extension Edu., 24:362-365.

Sreenivasreddy MV 1995. A Study on knowledge and adoption of recommended mango cultivation practices among farmers of Kolar districts. MSc(Agric)thesis, University of Agricultural Sciences, Bangalore, Karnataka, India.

Sudhakar B 2002. Awareness and adoption of integrated pest management practices in cotton cultivation. J. Extension Edu., 13(3):3364-3367.

Wase RB 2010. Knowledge and adoption of farmers about Jayanti chilli cultivation. MSc(Agric)thesis, Dr. Punjabrao Deshmukh Krishi Vidyapeeth, Akola, Maharashtra, India.

\section{How to cite this article:}

Sureshbabu, B. Zaheer Ahamed, Basayya and Jayalakshmi, S.K. 2017. Adoption of Banana Disease Management Practices and Constraints of Banana Growers in Kalaburagi District of Karnataka, India. Int.J.Curr.Microbiol.App.Sci. 6(12): 1177-1179. doi: https://doi.org/10.20546/ijcmas.2017.612.132 